\title{
Potential of Technology Startups to Bring Down Under- Employment among Engineering Students
}

Roopa Revathy $\mathrm{R}^{*}$

\begin{abstract}
For an effective use of India's youth population, better infrastructure, opportunities for development and employment must be provided. According to All India Council for Technical Education, more than $60 \%$ of eight lakh engineers graduating every year remain unemployed (2017). This is a loss of 20 lakh man days annually. This occurs not only due to the shortage of jobs but also as a result of the unemployability of students. The skills of engineers need to be used through start-ups that would provide an opportunity for innovation. This paper focusses on the problems faced by start-ups in engineering colleges and the opportunities for technology start-ups.
\end{abstract}

Keywords: Technology start-ups, Incubators,

\section{Introduction}

In a country like India, with proper initiatives, creativity can be constructively used in new fields. The youth of the country are its most valuable resource. There are many engineering students with new ideas but there are roadblocks that hinder their transformation into a start-up. A good scientific technology eco-system is needed to enable the youth to use their true potential and talent. The number of engineering institutes has multiplied 76 times when compared to the engineering institutes at the time of independence

* Government College for Women, Thiruvananthapuram, Kerala, India; rooparevathyr@gmail.com 
(Sanjay \& Vivek, 2017). However, the availability of many higher education institutes is not a yardstick for economic growth. As per the study made by the All India Council for Technical Education, $80 \%$ of engineering graduates in India are unemployable.

Underemployment is a situation where the workers are employed below their educational level or skill. It is a social problem that narrows the opportunity of people for updating skills, training, and growth in their respective educational fields. Most of the engineering graduates believe that their fields do not offer better jobs which force them to move to jobs that are inappropriate to their skills. Students need to build start-ups using skills and ideas in their respective fields. A tech startup is a company that aims to provide technology-based products and services to the market. They can use new technology or the existing technology in a new way (www.foundersclub.com). India's start-up ecosystem is at a nascent stage. Almost $50 \%$ of the founders in advanced tech startups come from an engineering background (NASSCOM). A strong support is needed to bring out the innovators and technopreneurs in students.

\subsection{Need and significance}

Creating jobs is required for the growth of this country. A reduction in the number of unemployed graduates is a must for the country. India needs new generations who are risk takers and can create start-ups along with engineering studies. The growing need for jobs is going to be catered through new start-ups. We need to promote technology start-ups for giving employment to students and using innovative techniques in all sectors of the country.

\subsection{Statement of the problem}

The challenge India is facing now is in making its graduates employable. Of around the 8,00,000 engineering graduates that India produces every year, $60 \%$ remain unemployed (Study by All India Council of Technical Education, 2017). Engineering graduates are either forced to do jobs which do not require a degree or do part-time jobs where they do not need to showcase their talent and skill and at times they get no jobs at all. This terrible situation leads to poverty in the country. Recent reports focus on the growing 
unemployability of engineering graduates and the declining interest of students in engineering education. About $80 \%$ of engineering students are unemployable and $50 \%$ of the seats in engineering colleges are vacant (National Employability Report 2015-16). There is a decline in the interest of society in engineering education and that has led to engineering seats being vacant. It is now common that engineering graduates do jobs that are not related to their studies. Their talents and ideas are not used in relevant areas. There is a wide gap between the opportunity for technology start-ups and the unemployment among engineering students.

\subsection{The scope of the study}

Innovation and entrepreneurship are not only for the Information Technology sector but also useful for fields like agriculture, traditional industries, artificial intelligence and so on. India's tech start-up ecosystem shows an exciting and sustained growth. One of the reasons for the development of tech start-ups is the rise of the Incubator/Accelerators in the ecosystem. Today there are over 190 active incubators/accelerators in the ecosystem and this sector is growing over 35\% since 2016 (NASSCOM). Academic incubators are around $45 \%$ of total incubators/accelerators in the system. Engineering students are now going for jobs which do not require an engineering degree. Recent developments in robotics industries, agriculture, artificial intelligence and machine learning are lucrative fields for tech start-ups to make innovations. Old technologies are becoming outdated and new technologies are gradually taking over. For running the venture, updated technologies are needed. Therefore, the best way is to innovate and build start-ups.

\subsection{Objectives}

- To analyse the opportunities available for technology startups

- To identify the problems faced by technology start-ups in engineering colleges 


\section{Methodology}

Three Engineering Colleges in Thiruvananthapuram district in Kerala namely Sree Chitra Thirunal College of Engineering-Trivandrum, Government Engineering CollegeBarton Hill-Trivandrum, and College of EngineeringTrivandrum were chosen for the study by convenience sampling method. A total of 30 technology start-ups were selected from the above-mentioned colleges with a representation of 10 start-ups from each college. The primary data was collected through a structured questionnaire from students who are running start-ups and secondary data was collected from journals, articles, websites, and books. The data so obtained was analysed using statistical techniques like percentage and one sample $\mathrm{T}$ test.

\section{Review of literature}

In studying the initiatives of Scottish University to build student start-ups and the lessons that it could hold for Ghana when unemployment is high, Richard \& Richard (2013) argued that entrepreneurship education with employability skills help to solve graduate unemployment. They said that entrepreneurship education with employability skills and a healthy economy is needed for its success. They need to consider culture, opportunities, and needs of the market, laws, public support, infrastructure, and above all, socioeconomic environment for building start-ups for reducing unemployment. They concluded that entrepreneurship education does not have a direct solution to graduate unemployment in Ghana. They have to consider other factors like economy, opportunities, market needs in the country and so forth.

In a study on Malaysian technical graduates, Ahmad, Baharun and Haslianah (2004) found that technical students were ready to select entrepreneurship as their career. 
Entrepreneurship education should be provided to nonbusiness disciplines where business and product ideas emerge. Unemployment in engineering students was reduced by providing better opportunity, creativity, favourable circumstances, necessary training, and self-confidence to students.

University of Michigan's TechArb, an accelerator which has an Entrepreneurship clinic. It offers various legal services in intellectual property protection, securities, regulations issues, and employment issues. Entrepreneurship clinic includes faculty who are licensed attorneys and second and third year law students who provide strategic and quality legal assistance to start-ups (Thompson, 2013).

Researchers argued that entrepreneurship education should be field oriented and have practical approaches (Omogbolahan, 2012). A partnership is needed for bridging the gap between higher education institutions and the industry.

There are however a few barriers in business establishments like finance, exploitation of business ideas, and absence of business advisory services. He recommended that a Student Enterprise Centre should provide advice, mentorship and practical support to students for self-employment (Ansah, 2012).

Judith (2013) found that the level of interest in entrepreneurship of male students is more than female students. Female students focussed on business ideas that have less economic impact while the male students' ideas have more economic impact. Female students' ideas would require low capital and have less risk. Male students' ideas need huge capital outlay and have high risk. 


\section{Growth in Technology}

A 'tech start-up' is a company created to develop new technology based products/services or to deliver existing tech based products/services in new and interesting ways (http://foundersclub.com). 'Tech' refers to software and hardware. Following are the different types of tech start-ups:

1. Consumer software start-up is a technological company which deals with delivering products/services to individuals through programmes that operate on a computer/mobile.

2. Consumer hardware start-up is a technology company which delivers products/services to individuals through physical electronic devices.

3. Enterprise software start-up delivers products/services to business through programmes that operate on a computer or a mobile.

4. Enterprise hardware start-up deals with products/services to business through physical electronic devices.

In the years to come, $70 \%$ employment is going to be generated in technical fields and opportunities in agri-business engineering, cloud platforms, big data, mobile analytics, Deep Tec (artificial intelligence, machine learning, Natural language processing, blockchain) and internet of things, hardware and wearable technologies would be available. In all the sectors, Artificial Intelligence will show its power. Artificial Intelligence will give benefits to farmers, manufacturers, and entrepreneurs. Artificial Intelligence will not reduce employment opportunities. It will create new and innovative employment opportunities in all sectors. 
Table 1 Number of new advanced tech start-ups incorporated (Source: NASSCOM-Zinnou Report 2017)

\begin{tabular}{l|r|r}
\hline Advanced Tech start-ups & \multicolumn{1}{|c|}{2015} & 2016 onwards \\
\hline Analytics/Advanced analytics & 90 & 125 \\
Artificial intelligence & 40 & 70 \\
Internet of Things & 45 & 55 \\
Robotics & 12 & 15 \\
3D printing & 8 & 10 \\
Augmented reality/Virtual reality & 20 & 25 \\
Blockchain & 5 & 8 \\
\hline Total & 220 & 308 \\
\hline
\end{tabular}

\subsection{Cognitive artificial intelligence}

Artificial intelligence is defined as "the theory and development of computer systems to be able to perform tasks that normally require human intelligence such as visual perception, speech recognition, decision-making, and translation between languages." (NASSCOM)

Below are some of the most important cognitive technologies:

- Machine learning refers to the ability of computer systems to improve their performance by being exposed to data without the need to follow explicitly programmed instructions. Machine learning is the process of automatically discovering patterns in data. Once discovered, the pattern can be used to make predictions.

- Natural language processing refers to the ability of computers to work with texts the way humans do. For instance, extracting meanings from texts or even generating a text that is readable, stylistically natural, and grammatically correct.

- Speech recognition focusses on automatically and accurately transcribing human speech.

- Computer vision refers to the ability of computers to identify objects, scenes, activities, and images.

- Machine vision, a related discipline, usually refers to vision applications in industrial automation where computers 
recognise objects such as manufactured parts in a highly constrained factory environment.

- Robotics - It integrates cognitive technologies such as computer vision and automated planning with tiny, high performance sensors, actuators, and cleverly designed hardware, giving rise to a new generation of robots that can work alongside people and perform many different tasks in an unpredictable environment.

\subsection{Digital realities}

- Virtual Reality (VR) creates a digital environment that replaces the user's real-world environment. VR is primarily used in gaming and entertainment applications.

- Augmented Reality (AR) overlays digitally-created content into the user's real-world environment for instance, projecting sales and inventory data onto products on store shelves.

- Mixed Reality (MR) is a mix of VR and AR creating an environment in which digital and physical objects can interact.

\subsection{Internet of things}

Internet of Things (IoT) adoption in India is projected to grow across industries by 2020. For example, industries such as Utilities, Manufacturing, Automotive and Transportation and Logistics will see the highest adoption levels in India. Innovation in products/services is an outcome of IoT apps which leads to differentiated products/services, improved operations and therefore better customer service.

\subsection{Blockchain}

Blockchain is the technology designed to make transactions (or data) more secure by recording the information in not just one location but over a network of computers. Very unique characteristics of Blockchain create a unique potential to transform the financial services infrastructure. 


\section{Analysis and interpretation}

\subsection{Influence to start a venture}

A majority of students remained uninfluenced by their families, relatives, seniors and peers. We found that $56.7 \%$ of students were influenced by the needs of the society. A majority of students went for start-ups after they identified the needs of the society. Government policies and programmes for start-ups have not been able to create a considerable impact on students. $50 \%$ of students were influenced by the activities and motivation provided by their teachers and college authorities. Survey results are given below.

Table 2 Influence to start a venture

\begin{tabular}{|c|c|c|c|c|c|c|}
\hline $\begin{array}{l}\text { Sl. } \\
\text { No }\end{array}$ & Factors & $\begin{array}{c}\text { Not at all } \\
\text { influenced } \\
\%\end{array}$ & $\begin{array}{c}\text { Slightly } \\
\text { influenced } \\
\%\end{array}$ & $\begin{array}{c}\text { Somewhat } \\
\text { influenced \% }\end{array}$ & $\begin{array}{c}\text { Very } \\
\text { influenced } \\
\%\end{array}$ & $\begin{array}{c}\text { Extremely } \\
\text { influenced } \\
\%\end{array}$ \\
\hline 1 & $\begin{array}{l}\text { Government } \\
\text { initiatives for } \\
\text { start-ups }\end{array}$ & 16.7 & 6.7 & 46.7 & 10 & 20 \\
\hline 2 & $\begin{array}{l}\text { Teachers, } \\
\text { College } \\
\text { authorities }\end{array}$ & 6.7 & 10 & 26.7 & 50 & 6.7 \\
\hline 3 & $\begin{array}{l}\text { Successful } \\
\text { entrepreneur } \\
\mathrm{s}\end{array}$ & 10 & 20 & 10 & 46.7 & 13.3 \\
\hline 4 & $\begin{array}{l}\text { Needs of the } \\
\text { society }\end{array}$ & 0 & 0 & 3.3 & 56.7 & 40 \\
\hline 5 & $\begin{array}{l}\text { Family/ } \\
\text { Relatives }\end{array}$ & 40 & 33.3 & 16.7 & 10 & 0 \\
\hline 6 & Seniors & 50 & 16.7 & 23.3 & 0 & 10 \\
\hline 7 & Peers & 36.7 & 10 & 36.7 & 16.7 & 0 \\
\hline
\end{tabular}

\subsection{Facilities provided by incubation centres}

Start-up incubators help in promoting speedy growth and support for startups. $26.7 \%$ of students were not at all satisfied with the funding provided by incubators and only $10 \%$ of students said that they were satisfied with the funding provided by incubators. $13.3 \%$ of students said that they were satisfied with the marketing assistance of incubators. Nobody felt extremely satisfied with the funding and marketing assistance of incubators. $40 \%$ of the students were satisfied with the infrastructure facilities in incubators. Survey results are given below. 
Table 3: Opinion about facilities provided by incubation centres

\begin{tabular}{clccccc}
\hline $\begin{array}{c}\text { Sl. } \\
\text { No. }\end{array}$ & Facilities & $\begin{array}{c}\text { Not at } \\
\text { all } \\
\text { satisfied } \\
\%\end{array}$ & $\begin{array}{c}\text { Slightly } \\
\text { satisfied } \\
\%\end{array}$ & $\begin{array}{c}\text { Moderately } \\
\text { satisfied } \\
\%\end{array}$ & $\begin{array}{c}\text { Very } \\
\text { satisfied } \\
\%\end{array}$ & $\begin{array}{c}\text { Extremely } \\
\text { satisfied } \\
\%\end{array}$ \\
\hline 1 & Funding & 26.7 & 36.7 & 26.7 & 10 & 0 \\
2 & Infrastructure & 0 & 23.3 & 6.7 & 40 & 30 \\
3 & Mentoring & 0 & 26.7 & 36.7 & 16.7 & 20 \\
4 & Marketing & 26.7 & 33.3 & 26.7 & 13.3 & 0 \\
& assistance & & & & & \\
\hline
\end{tabular}

\subsection{Impact made by start-ups}

Students have different views about start-ups and its impact. Most of the students said that start-ups were not leading to wastage of funds and resources (43.3\%). They strongly agreed that start-ups provided opportunity to use skilled man-power (56.7\%) and social welfare $(56.7 \%)$ which led to economic growth $(56.7 \%) .83 .3 \%$ of students strongly agreed that start-ups provided an opportunity to use their knowledge. Only 10\% students agreed with the statement that start-ups led to the wastage of funds. Survey results are given below.

Table 4 Opinion about impact of start-ups

\begin{tabular}{clccccc}
\hline $\begin{array}{c}\text { Sl. } \\
\text { No. }\end{array}$ & \multicolumn{1}{c}{ Impact } & $\begin{array}{c}\text { Strongly } \\
\text { disagree } \%\end{array}$ & $\begin{array}{c}\text { Disagree } \\
\%\end{array}$ & $\begin{array}{c}\text { Neutral } \\
\%\end{array}$ & $\begin{array}{c}\text { Agree } \\
\%\end{array}$ & $\begin{array}{c}\text { Strongly } \\
\text { agree } \\
\%\end{array}$ \\
\hline 1 & $\begin{array}{l}\text { Increased } \\
\text { employment } \\
\text { opportunities }\end{array}$ & 0 & 6.7 & 40 & 36.7 & 16.7 \\
2 & $\begin{array}{l}\text { Wastage of funds, } \\
\text { resources }\end{array}$ & 20 & 43.3 & 26.7 & 10 & 0 \\
3 & $\begin{array}{l}\text { Economic growth } \\
4\end{array}$ & 0 & 0 & 23.3 & 20 & 56.7 \\
& $\begin{array}{l}\text { Opportunity to } \\
\text { use skilled } \\
\text { manpower }\end{array}$ & 0 & 0 & 16.7 & 26.7 & 56.7 \\
5 & $\begin{array}{l}\text { Social welfare } \\
\text { Opportunity to } \\
\text { use knowledge }\end{array}$ & 0 & 10 & 26.7 & 6.7 & 56.7 \\
& & 0 & 6.7 & 10 & 83.3 \\
\hline
\end{tabular}

\subsection{Problems faced while running the venture}

Start-ups have been facing various problems in this ecosystem. The various problems were identified as insufficient funds, inadequate mentoring, lack of experience, cyber risks, stiff competition, 
changing technology, and Government rules and regulations. Problems were measured on 4-point scale like not at all a problem, minor problem, moderate problem, serious problem, which were assigned the weights of 1,2,3 and 4 respectively. The problems which got a weighted mean of more than 2.5 points show that respondents were facing above average problems. The above average problem they were facing were: 'insufficient funds' (mean3.50),'Government rules and regulations' (mean3.03),'inadequate mentoring' (mean-2.67). The below average problems were 'lack of experience' (mean-2.30),' cyber risks' (mean-2.13),'changing technology' (mean-2.00). This implies that insufficient funds and Government rules and regulations were serious problems for tech start-ups. Survey results are given below.

Table 5 Problems faced while running the venture Test value 2.5

\begin{tabular}{lrrrr}
\hline & $\mathrm{N}$ & \multicolumn{1}{c}{ Mean } & Std. Deviation & Std. Error Mean \\
\hline Insufficient funds & 30 & 3.50 & .682 & .125 \\
Inadequate mentoring & 30 & 2.67 & 1.213 & .221 \\
Lack of experience & 30 & 2.30 & 1.088 & .199 \\
Cyber risks & 30 & 2.13 & 1.008 & .184 \\
Stiff competition & 30 & 2.47 & 1.196 & .218 \\
Changing technology & 30 & 2.00 & .643 & .117 \\
Government rules and & 30 & 3.03 & .999 & .182 \\
regulations & & & & \\
\hline
\end{tabular}

\subsection{Financial problem in the venture}

Finance is always a major issue for every organisation. Here some of the financial problems faced by student start-ups were identified as high interest rate for loans, unstable cash flow, too many formalities in granting loan, lack of collateral security, and lack of financial knowledge. A 4-point scale has been used here, like not at all a problem, minor problem, moderate problem, serious problem, which were assigned the weights $1,2,3$, and 4 respectively. The items which got a mean value higher than 2.5, showed that students were facing an 'above average problem' in those items. Here all the problems were above average level. It means all 
problems related to finance have been a major issue for them. The survey results are given below.

Table 6 Opinion about financial problems in the venture Test value 2.5

\begin{tabular}{lrrrr}
\hline & N & Mean & \multicolumn{1}{c}{$\begin{array}{c}\text { Std. } \\
\text { Deviation }\end{array}$} & $\begin{array}{c}\text { Std. Error } \\
\text { Mean }\end{array}$ \\
\hline High interest rate for loans & 30 & 2.93 & 1.172 & .214 \\
Unstable cash flow & 30 & 3.23 & .568 & .104 \\
Too many formalities for granting & 30 & 3.50 & .682 & .125 \\
loan & & & & \\
Lack of collateral security & 30 & 2.93 & 1.081 & .197 \\
Lack of financial knowledge & 30 & 2.80 & .610 & .111 \\
\hline
\end{tabular}

\section{Suggestions for improvement of start-up ecosystem}

Efficient start up ecosystem boosts the growth of start-ups. Here are some suggestions for the improvements in start-up ecosystem and students need to give their response on the desirability of the needs. They are Single Window System, Deemed license, Improvements in infrastructure, Adequate changes in labour laws, Easy availability of loan, Tax exemptions, Funding opportunities, Water and electricity in subsidised rate, Grievance redressal system, Skill Development programs. These are measured on a 5point scale like Very undesirable, Undesirable, Neutral, Desirable, very desirable which were assigned the weights like 1,2,3,4, and 5 respectively. Mean value above 3 states that they are above average desires. They have above average desires in all the suggestions. They need more funding opportunities and easy availability of loan. Survey results are given below. 
Table 7 Suggestions for improvement in start-ups Test value 3

\begin{tabular}{lrrrr}
\hline & N & Mean & $\begin{array}{c}\text { Std. } \\
\text { Deviation }\end{array}$ & $\begin{array}{c}\text { Std. Error } \\
\text { Mean }\end{array}$ \\
\hline Tax exemptions & 30 & 4.20 & .847 & .155 \\
Single Window System & 30 & 4.13 & .973 & .178 \\
Deemed license & 30 & 3.20 & .961 & .176 \\
Improvement in infrastructure & 30 & 4.23 & .971 & .177 \\
Adequate changes in labour laws & 30 & 3.70 & 1.179 & .215 \\
Easy availability of loan & 30 & 4.73 & .450 & .082 \\
More funding opportunities & 30 & 5.00 & .000 a & .000 \\
Water and Electricity in subsidised rate & 30 & 4.10 & .845 & .154 \\
Grievance redressal system & 30 & 4.37 & .718 & .131 \\
Skill Development Programs & 30 & 4.63 & .669 & .122 \\
\hline Source Primary source & & & &
\end{tabular}

Source: Primary source

\section{Findings}

- Government initiatives like start-up policies and programmes have not highly influenced the students for building their start-ups. It was clear that Government programmes have not achieved its aim for start-ups.

- Successful entrepreneurs have always been a good role model for students. They have been more influenced by successful entrepreneurs. The motivation and guidance given by them boosted the minds of students and attracted more students to start-ups.

- Students have started their ventures mainly for satisfying the needs of the society.

- Seniors, peers, family members, relatives have not created a greater influence on students. The attitude of the society towards start-ups has always been negative and it has been found that since the start-up activities of their seniors were not a success, it did not influence them in starting their business.

- Students are not satisfied with the funding and marketing assistance provided by incubators. 
- Most of the students agree that start-ups lead to growth of the economy, social welfare and it provides an opportunity to use skilled manpower and knowledge.

- Students disagree that start-ups are wastage of funds and resources. They are ready to use finance and other resources to make their start-ups a successful one.

- Insufficient funds, strict Government rules and too many regulations are some of the serious problems faced by startups.

- Government and other agencies have been taking many actions for mentoring student entrepreneurs. Students said that they didn't get sufficient mentoring and motivational support.

- Start-ups are facing many problems in financial areas like, high rate of interest for loans, unstable cash flows, formalities in granting loans from financial institutions, lack of collateral security and lack of financial knowledge. Unstable cash inflow and outflow has been a problem for better financial planning.

- Start-ups need more funding opportunities which has been one of the most important suggestions from the students.

- Skill development programmes, grievance redressal system for entrepreneurs, single window system for getting approvals and licences, deemed license which guarantees approval or rejection of application within 30 days, actions for easy availability of loan are also important suggestions made by them.

- Some students are engaged in start-ups only for getting grace marks and sometimes stop their start-ups when placed in new companies.

\section{Suggestions}

- Government programmes for building a start-up ecosystem in the country must reach students with all its benefits. 
Conducting awareness programmes in colleges about the sources of funds, opportunities in the market, changes in their start-up eco system, Government programmes and policies could be beneficial.

- Conducting interactive sections with successful entrepreneurs within the college to boost motivation in students could also be a good step.

- Keeping the society aware about the need and the importance of start-ups and developing a positive attitude towards student start-ups can be a good initiative.

- Motivating students to grow with their start-ups when they get new jobs can be beneficial.

- Start-up incubators must promote the speedy growth and success by increasing its efficiency and providing better facilities along with mentoring and guiding student startups.

- Concessions could be given for student start-ups in case of Government rules and regulations for creating student start-ups.

- Better funding opportunities, loans at low rates, easy licensing procedures are needed. This is possible through initiatives by the Government and financial organisations.

- Bridging the gap between industries and business ideas of students is important.

- Taking actions for providing quick supply of materials from the Government to student start-ups can be helpful.

- Better start-up policies for each state must be designed after analysing the system.

\section{Conclusion}

From 2018 onwards, there will be a revolutionary change in skill development, innovations, and technology and it will create more employment opportunities in agri-business, retailing, connectivity, automobile, health technologies, food processing, logistics, robotics 
and so forth. Innovations using technologies will help in accelerating India's economic growth. Talents of engineering students in technologies need to be nurtured, mentored, and they need support from the Government, investors as well as the industries. It is the responsibility of authorities and the society to solve the problems faced by start-ups and its growth will reduce the unemployment of engineering students. The goal of every innovation must be to improve the standard of living of people and to provide solutions to their problems.

\section{References}

Ahmad, F., \& Baharun, R., \& Haslianah, S. (2004). Interest in entrepreneurship: An exploratory study on engineering and technical students in entrepreneurship education and choosing entrepreneurship as a career. Project submitted in Technical University of Malaysia. Retrieved from http://s3.amazonaws.com/ academia.edu.documents as on 5/12/17

All India Council of Technical Education. (2017).' $60 \%$ of engineering graduates unemployed'. Times of India. Retrieved from http:/ / timesofindia.indiatimes.com as on 11/12/17.

Ansah, P. (2012). Entrepreneurship education, a panacea to graduate unemployment in Ghana. International journal of humanities and social science, 2(15). Retrieved from www.ijhssnet.com as on 7/12/17.

Fosu, R., \& Richard, B.E. (2013). The Scottish University level entrepreneurship education initiative: Lessons for Ghana in dealing with graduate unemployment. Journal of Education and Practice, 4(24). Retrieved from www.iiste.org as on 2/12/17.

Founders Club-Education center. (2017).'Exploring the Tech start-up space'. Retrieved from http:/ / foundersclub.com as on 5/12/17

Judith, Z. (2013). Entrepreneurship education -An alternative route to alleviating unemployment and the influence of gender: An analysis of University level students entrepreneurial business ideas. International Journal of Business Administration, 4(2).Retrieved from www.sciedu.ca/ijba.com as on 9/12/17

NASSCOM. (2017). 'India's Tech start-up ecosystem: Rising and shining'. Newsline, 8(7). Retrieved from http://www.nasscom.in/ nasscomnewsletter/newsline as on 20/12/17. 
NASSCOM. (2017). Technological disruptions and their transformational impact.Newsline, 8(8).Retrievedfrom htttp://www.nasscom.in/ nasscom-newsletter/nasscom-newsline as on 2/12/17.

NASSCOM-Zinnov Report (2017). Indian start-up ecosystem-transferring the maturity cycle. Retrieved from www.nasscom.in/knowledgecenter/publications as on 3/12/17.

Omogbolahan, S. (2012). Entrepreneurial education as a tool for reducing unemployment in Nigeria. Dissertation submitted to The School of Postgraduate studies, Babcock University, Nigeria for partial fulfilment of Degree of Masters in Public Management. Retrieved from http://s3.amazonaws.com/academia.edc.documents as on $4 / 12 / 17$.

Sanjay, D., \& Vivek, M. (2017). Education beyond marks and degrees. Science Reporter, 54(2), 37-40.

Thompson, D. (2013). Accelerating the growth of the next generation innovators. Ohio State Entrepreneurial Business Law Journal, 8(2). Retrieved from http:// respository.law.umichu.edu/articles as on $4 / 12 / 17$. 